\title{
Bishop Wilberforce: Natural Selection and the Descent of Man
}

\author{
from Richard $W$. Wrangham
}

Samuel Wilberforce, Bishop of Oxford, was the man who played into T.H. Huxley's hands at the British Association's meeting in 1860 . They were debating the merits of Darwinism, and the atmosphere in the crowded room was highly charged. Wilberforce was a fine speaker - "Like an olive, his nature secretes his own oil"', wrote $P_{\text {unch }}^{1}$ - and he ended his wellprepared attack on evolutionary theory by asking if his opponent were prepared to admit apes to his own ancestry. The reply was deadly. An ape, said Huxley, would be a preferable grandfather to an intelligent man who used his skills to bring ridicule to

\author{
science. ${ }^{2}$ It won the audience and silenced \\ the Bishop, who never spoke again on \\ evolution.
} Huxley went on to build a career out of undated. Its theme, "degradation by promoting Darwinism, while Wilberforce natural selection"', is from Richard Owen's returned to ecclesiastical matters. But how review of the Origin. ${ }^{5}$ Wilberforce saw all did he come to feel about evolution? His too well the clash between evolutionary only published opinion was a review of the theory and his religious beliefs, and in 1860 Origin of Species, written before the debate he had come out in attack. But in this poem with Huxley. ${ }^{3}$ There he denied he side-stepped the conflict and retreated unambiguously that evolution was tenable, to comedy. It implies a man too committed though he approved of natural selection. to accept the evolutionary argument, yet He understood the arguments well and too honest in the end to deny it. Who used them to maintain that selection acted knows? Darwin may have had one more to keep species constant, not to change them ${ }^{4}$. convert than he knew.

\section{"Lines written on hearing that Professor Huxley had said that "he did not care} whether his grand-father was an Ape'.,

Oft had I heard, but deemed the tale untrue, That man was cousin to the Kangaroo;

That he before whose face all nature quailed, Was but the monkey's heir, though unentailed; And that the limber Ape, whose knavish ways And tricks fantastic oft our laughter raise, Was just what we were in some previous state, Ages ere Noah shipped his living freight. But now a learn'd Professor, grave and wise, Stoutly maintains what I supposed were lies; And, while each listening sage in wonder gapes, Claims a proud lineage of ancestral Apes. Alas! cried I, if such the sage's dreams, Save me, ye powers, from these unhallowed themes;
From self-degrading science keep me free, And from the pride that apes humility!

But $O$ should fate bring back these dreams accursed,

And shuddering Nature find her laws reversed;

Should this, the age of wonders, see again

Men sunk to monkeys, monkeys raised to men:

Be mine the lot, on some far-distant shore,

Where Science wearies not nor savants bore -

Where no learn'd Apes our fallen race may scorn,

Nor point the moral which our tails adorn -

To shun the sight of metamorphosed friends,

Till time again shall shape their altered ends,

To soothe each fond regret, howe'er I can;

And, at the least, to dream myself a Man!

S. Wilberforce

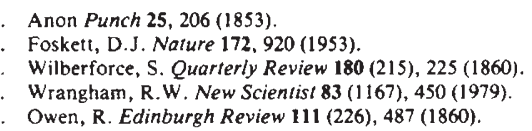

Richard W. Wrangham is in King's College, Cambridge.

have properties that are readily observed in vitro and are clearly distinct from those of the unphosphorylated protein. The influence of phosphorylation on the potentiation of the actin-activated myosin MgATPase has been the major focus of attention. Upon phosphorylation of the myosin light chain, the MgATPase activity of the protein in the presence of actin is increased ten- to twentyfold ${ }^{12}$.

A third manifestation of the effect of myosin phosphorylation has now been observed in vitro with myosin from smooth muscle and nonmuscle cells. Working with myosins from thymus, platelets and gizzard, John Kendrick-Jones et al. show in this issue of Nature (p.233) that bipolar thick filaments are formed under physiological conditions only if the myosins are phosphorylated. These synthetic thick filaments are stable in the presence of millimolar concentrations of MgATP. Shorter filaments are formed of un- phosphorylated myosins in vitro at low ionic strength, but these are completely dissociated well below physiological concentrations of MgATP. These results are a striking extension and confirmation of the work by Hiroshi Suzuki and his collaborators at the Tokyo Institute of Technology ${ }^{13}$ who first observed that the state of gizzard myosin phosphorylation has a profound effect upon the ability of the protein to form extended aggregates.

The observations of Suzuki and of Kendrick-Jones are particularly important because they resolve some puzzles and raise some interesting questions. If smooth muscle and non-muscle myosin must be phosphorylated in order to form thick filaments in vivo, then the absence of such filaments in many electron micrographs of smooth muscle and nonmuscle cells might be explained by the absence of phosphorylated myosin. Furthermore, another possible function of phosphorylation in striated muscle becomes clear phosphorylated, striated muscle myosin may constitute thick filaments more stable and/or more ordered than the unphosphorylated myoisin.

The questions are intriguing. How does filament formation contribute to the observed actinactivation of the smooth muscle and nonmuscle MgATPase? Is actin-activation due to an increased order in the myosin array and, therefore, to an increased accessibility of myosin to actin? Another very important question raised by Kendrick-Jones has to do with how modification of the head portion of myosin might influence the association and packing of the opposite, tail portion of the molecule. No doubt subsequent studies by these and other investigators will address these problems and will shed even more light upon the nature of the finely tuned control in the contractile protein complex. 